\title{
Nitrogen balance in Indian preschool children receiving the safe level of protein at varying levels of energy
}

\author{
BY ASHOK K. IYENGAR, ${ }^{*}$ B. S. NARASINGA RAO† \\ AND VINODINI REDDY \\ National Instituie of Nutrition, Indian Council of Medical Research, \\ Jamai-Osmania, P.O., Hyderabad-500 007, India
}

(Received 17 July 1980 - Accepted 20 May 1981)

\begin{abstract}
1. A study was carried out to determine the effects of varying the level of energy intake on nitrogen balance in preschool children receiving the safe requirement level of protein, determined in an earlier study.

2. Seven preschool children received four energy levels, i.e. $293,334,376$ and $418 \mathrm{~kJ} / \mathrm{kg}$ body-weight at the safe level of protein intake of $1.75 \mathrm{~g} / \mathrm{kg}$ body-weight and $\mathrm{N}$ balance determined.

3. The $\mathbf{N}$ balance decreased with a decrease in energy intake. However, the $\mathbf{N}$ balance was positive at all levels of energy intake studied.

4. Results indicated that at a protein intake of $1.75 \mathrm{~g} / \mathrm{kg}$ body-weight the minimum level of energy intake for a retention of $40 \mathrm{mg} \mathrm{N} / \mathrm{kg}$ bod\%-weight in these children was found to be $326 \cdot 2 \pm 45 \cdot 5$ (mean $\pm \mathrm{SD}$ ) $\mathrm{kJ} / \mathrm{kg}$ body-weight. Below this energy intake the safe level of protein intake became inadequate.
\end{abstract}

Protein-energy malnutrition is a major nutritional problem among preschool children in many developing countries of the world. In order to define the extent of this problem, one must have a precise knowleidge of their protein and energy requirements. Results of several carefully-conducted diet surveys among Indian preschool children belonging to low-income groups subsisting on cereal-pulse diets have shown that their protein intakes correspond to currently recommended levels, while their energy intakes fail to meet their requirement (Narasinga Rao et al. 1969; Gopalan \& Narasinga Rao, 1971), and the average energy deficit is approximately $30 \%$. It is possible that in the face of this energy deficit their current protein intakes may not be adequate. However, not much information is available regarding protein requirements in Indian preschool children in relation to their energy intakes.

In a previous communication, Iyengar et al. (1979) reported that the safe level of protein intake for Indian preschool children is $1.75 \mathrm{~g} / \mathrm{kg}$ body-weight provided the energy intakes are adequate at $418 \mathrm{~kJ} / \mathrm{kg}$ body-weight. It is not clear however, whether this level of protein intake would be adequate in the face of inadequate energy intake usually observed among those children belonging to the low socio-economic group. Available information suggests that inadequate energy intake decreases protein utilization (Munro, 1951). It has been well documented that in adult men, at an adequate level of protein intake, the energy level becomes the deciding factor for $\mathrm{N}$ balance (Calloway \& Spector, 1954; Nageswara Rao et al. 1975). It was therefore considered important to determine the influence of variation in energy intakes on $\mathrm{N}$ metatiolism in preschool children receiving the safe level of protein. The present study was also aimed at determining the minimal energy intake below which the safe level of protein intake would become clearly inadequate to meet the protein needs of preschool children. Such information would be helpful in assessing the extent of protein deficiency in children with different extents of energy inadequacy.

\footnotetext{
* Present address: Planning Commission, Yojana Bhavan, Sansad Marg., New Delhi - 110001.

$\dagger$ For reprints.
} 
Table 1. Anthropometric measurements of Indian preschool children studied

\begin{tabular}{|c|c|c|c|c|c|c|c|c|c|c|}
\hline \multirow[b]{2}{*}{ Subject } & \multirow[b]{2}{*}{ Sex } & \multirow{2}{*}{$\begin{array}{c}\text { Age } \\
\text { (years) }\end{array}$} & \multirow{2}{*}{$\begin{array}{c}\text { Weight } \\
\text { (kg) }\end{array}$} & \multirow{2}{*}{$\begin{array}{l}\text { Height } \\
\text { (m) }\end{array}$} & \multicolumn{2}{|c|}{$\%$ Weight-for-age } & \multicolumn{2}{|c|}{$\%$ Height-for-age } & \multicolumn{2}{|c|}{$\%$ Weight-for-height } \\
\hline & & & & & $a$ & $b$ & $a$ & $b$ & $a$ & $b$ \\
\hline PS & o & $4 \cdot 0$ & 12.6 & 0.934 & 76 & 93 & 90 & 97 & 91 & 102 \\
\hline JP & 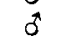 & 3.5 & 11.4 & 0.932 & 74 & 97 & 94 & 105 & 81 & 92 \\
\hline NS & 0 & 3.0 & 11.2 & 0.923 & 80 & 95 & 96 & 98 & 82 & 92 \\
\hline $\mathbf{R A}$ & 8 & 4.0 & 14.0 & 0.985 & 85 & 108 & 95 & 102 & 93 & 103 \\
\hline NR & $s^{\infty}$ & 3.5 & 12.4 & 0.875 & 80 & 92 & 87 & 91 & 100 & 108 \\
\hline NJ & $q$ & 4.0 & 14.0 & 0.954 & 85 & 108 & 92 & 101 & 98 & 106 \\
\hline RU & $a_{0}^{+}$ & 3.0 & $10 \cdot 3$ & 0.820 & 71 & 87 & 86 & 92 & 90 & 100 \\
\hline
\end{tabular}

$a$, Calculated from Jelliffe (1966); $b$, calculated from the Indian Council of Medical Research (1972).

Table 2. Composition of diets $(\mathrm{g} / \mathrm{kg}$ body-weight) fed to Indian preschool children

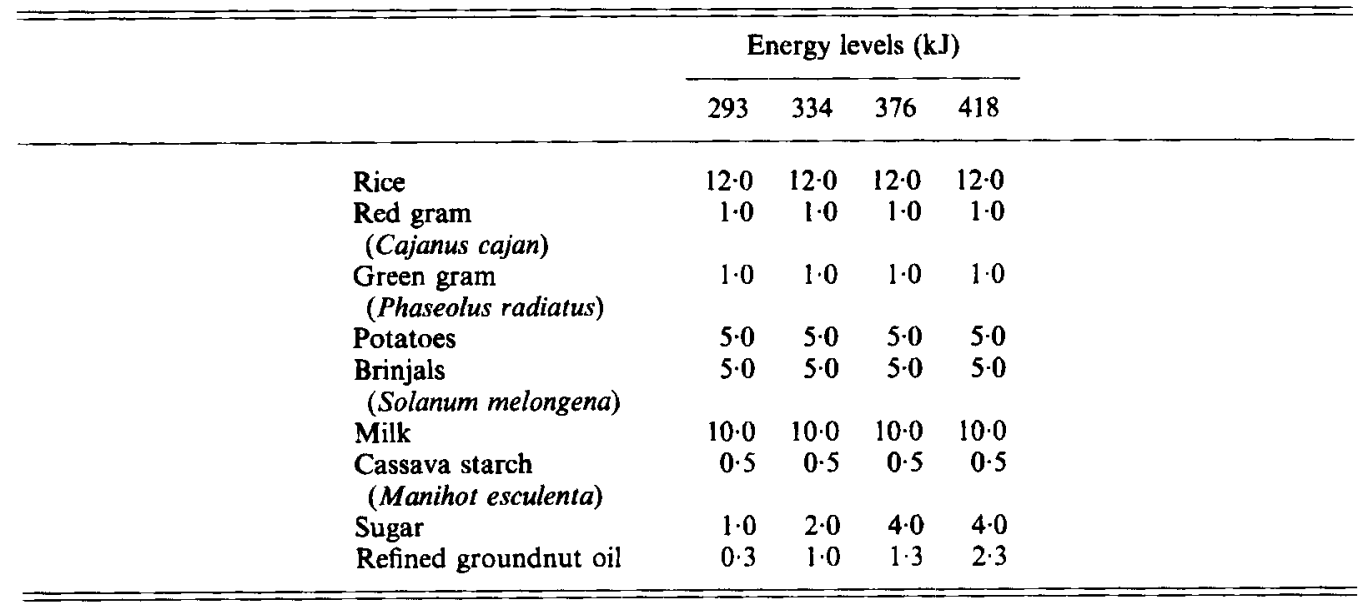

MATERIALS AND METHODS

Seven apparently-normal preschool children were admitted to the Nutrition Ward of the Niloufer Hospital, Hyderabad, India, and were under the supervision of a nurse throughout the study. Relevant details of the subjects are given in Table 1. Their heights and weights, although comparable to the standards for Indian children (Indian Council of Medical Research, 1972), were only $71-85 \%$ for weight and $86-96 \%$ for height as compared to International standards (Jelliffe, 1966). Although they were in the hospital, the children were not confined to bed except during sleep at night and their normal activities were not curtailed. Heights and weights of all subjects were recorded before the commencement of the experiment and weights were recorded daily. The experimental diet was formulated so as to correspond closely to their habitual diet which was determined by an oral questionnaire method. Their diets comprised mainly rice and small quantities of legumes, vegetables, milk, sugar and fat.

\section{Experimental diets}

The subjects received diets containing a protein level of $1.75 \mathrm{~g} / \mathrm{kg}$ body-weight and four levels of energy intake i.e. $293,334,376$ and $418 \mathrm{~kJ} / \mathrm{kg}$ body-weight $(70,80,90$ and $100 \mathrm{kcal} / \mathrm{kg}$ body-weight) respectively. The composition of the diets is given in Table 2 . The 


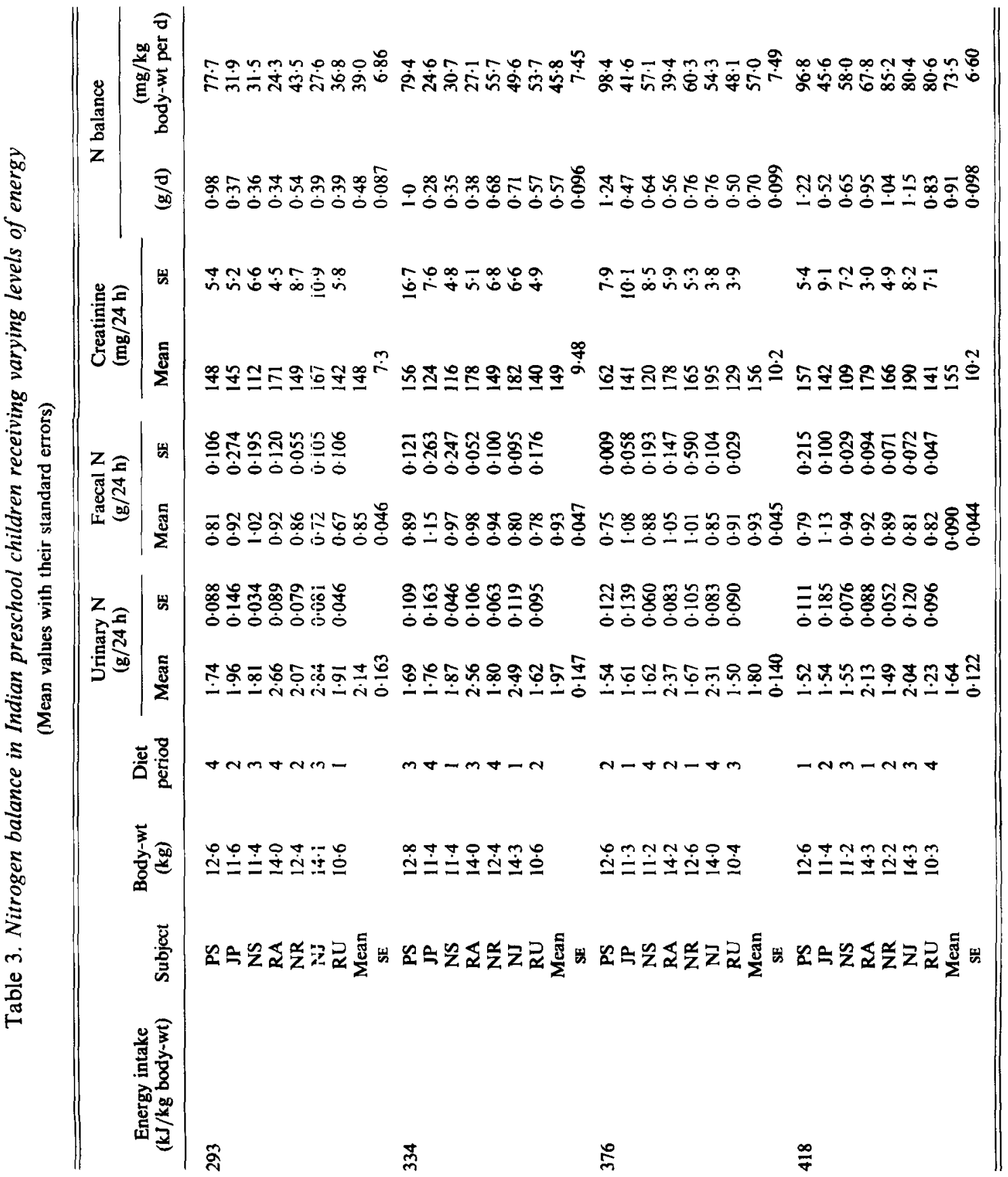


Table 4. ANOVA for data on nitrogen balances and energy levels

\begin{tabular}{lcccc}
\hline Source of variation & $\begin{array}{c}\text { Degrees of } \\
\text { freedom }\end{array}$ & $\begin{array}{c}\text { Sum of } \\
\text { squares }\end{array}$ & $\begin{array}{c}\text { Mean sum of } \\
\text { squares }\end{array}$ & $F$ ratio \\
\hline Between energy levels & 3 & 0.729011 & 0.2430 & $20.9 *$ \\
Between individuals & 6 & 1.304571 & 0.2174 & $18 \cdot 7^{*}$ \\
Error & 18 & 0.209514 & 0.0116 & - \\
Total & 27 & 2.243096 & 0.4720 & - \\
\hline
\end{tabular}

$* P<0.001$

cereal and pulse contents of the diets were kept constant while the sugar and fat contents were varied to achieve different energy levels.

\section{Experimental design}

Each of the subjects received diets at all four energy levels, each level being fed for a period of $11 \mathrm{~d}$. Urine and faeces ( $24 \mathrm{~h}$ samples in each instance) were collected during the last $4 \mathrm{~d}$ of each dietary regimen. Urine was collected under toluene and acetic acid and stored in the cold for subsequent analyses, while faeces were collected in suitable plastic containers. Urine and faeces were analysed for total N. Urine was also analysed for creatinine.

\section{Analytical methods}

Urine and faeces were analysed for total $\mathrm{N}$ by the macrokjeldhal method. Urinary creatinine was estimated by the method of Clark \& Thompson (1949) using tenfold dilution of urine.

\section{RESULTS AND DISCUSSION}

Values for $\mathrm{N}$ intake, faecal $\mathrm{N}$, urinary $\mathrm{N}, \mathrm{N}$ balance and creatinine excretion for individual subjects are presented in Table 3. Statistical analysis of the results was carried out by the two-way analysis of variance and the statistical significance was tested by the $t$ test. The results of analysis are given in Table 4.

$\mathrm{N}$ balance was positive in all the subjects on all four levels of energy intake studied. $\mathbf{N}$ retention tended to decrease as the energy decreased. However no meaningful mathematical relationship could be obtained between energy intake and $\mathbf{N}$ retention, although statistical analysis of $\mathbf{N}$ retention values in relation to energy intake revealed that $\mathrm{N}$ retention at an energy intake of $418 \mathrm{~kJ} / \mathrm{kg}$ body-weight was significantly $(P<0.01)$ higher when compared to $\mathrm{N}$ retention observed on intakes of $376 \mathrm{~kJ}, 334 \mathrm{~kJ}$ or $293 \mathrm{~kJ} / \mathrm{kg}$ body-weight. $\mathrm{N}$ retention at an energy intake of $376 \mathrm{~kJ} / \mathrm{kg}$ body-weight was significantly $(P<0.05)$ higher than at intakes of either $334 \mathrm{~kJ}$ or $293 \mathrm{~kJ}$ and $\mathrm{N}$ retentions at the latter two levels were not significantly different from each other. The increased $\mathrm{N}$ retention with increasing energy intake reported in the present study suggests a protein sparing action of energy, which has also been observed by several earlier workers (Plough et al. 1956; Inoue et al. 1973; Nageswara Rao et al. 1975). Munro \& Naismith (1953) showed in rats that even when the diet contained no protein, the addition of energy as carbohydrate produced a small improvement in $\mathrm{N}$ balance.

Urinary $\mathbf{N}$ excretion increased as the level of energy intake was decreased, reflecting the changes in $\mathrm{N}$ retention. However, neither faecal $\mathrm{N}$ excretion $(\mathrm{g} / \mathrm{d})$ nor urinary creatinine- $\mathrm{N}$ excretion $(\mathrm{g} / \mathrm{d})$ was affected by the level of energy intake. There was a significant inverse linear relationship between energy intake $(X ; \mathrm{kJ} / \mathrm{kg}$ body-weight per $\mathrm{d})$ and urinary $\mathrm{N}$ excretion $(Y ; \mathrm{g} / \mathrm{kg}$ body-weight per d) in each of the subjects (Table 5 ). 


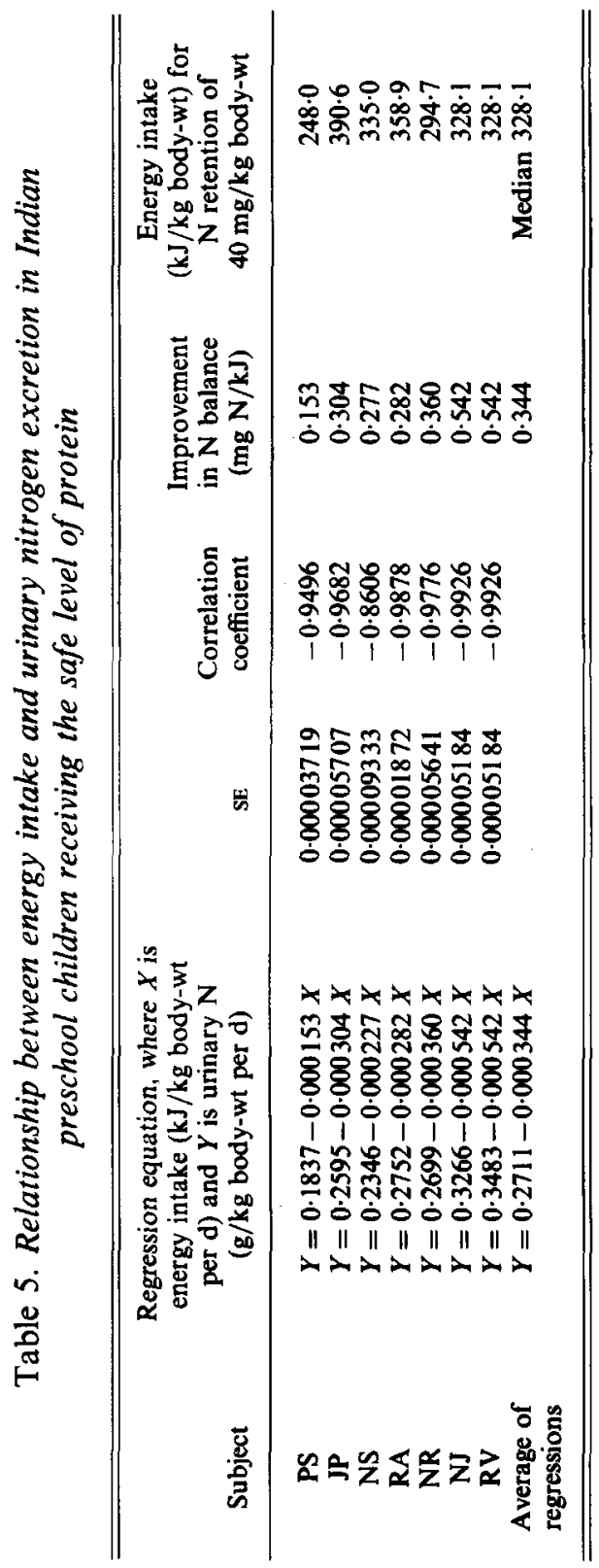


From the relationship between urinary $\mathrm{N}$ and energy intake, the mean improvement in $\mathrm{N}$ balance was found to be $0.34 \mathrm{mg} \mathrm{N} / \mathrm{kJ}(1.44 \mathrm{mg} \mathrm{N} / \mathrm{kcal})$.

The present study indicates that in children receiving a safe level of protein, a decrease in energy intake of $30 \%$, i.e. from 418 to $293 \mathrm{~kJ} / \mathrm{kg}$ body-weight did not result in negative $\mathrm{N}$ balance, although the retention had decreased significantly. An intake of $293 \mathrm{~kJ} / \mathrm{kg}$ body-weight in these children represents approximately their maintenance requirement, i.e. $1.5 \times$ basal requirement (Joint FAO/WHO Expert Committee on Energy and Protein Requirements, 1973). In contrast, in adults, an energy intake below the maintenance level resulted in negative $\mathrm{N}$ balance (Nageswara Rao et al. 1975). These observations suggest that there are differences between adults and children in their response to alterations in energy intake in $\mathbf{N}$ metabolism.

The level of energy intake below which the safe level of protein intake of $1.75 \mathrm{~g} / \mathrm{kg}$ body-weight becomes inadequate can be computed from the present information. In arriving at a safe level of protein requirement of these children, a retention of $40 \mathrm{mg} \mathrm{N} / \mathrm{kg}$ body-weight was considered to be adequate to meet their growth requirements (lyengar et al. 1979). From the previously-mentioned relationship between energy intake and urinary $\mathrm{N}$ loss and the observed faecal $\mathrm{N}$ loss (which was not related to energy intake), the minimum energy intake for a retention of $40 \mathrm{mg} \mathrm{N} / \mathrm{kg}$ body-weight was calculated and the values are given in Table 4. It can be seen that the minimum energy intake (mean $\pm \mathrm{SD}$ ) in these children for an $\mathrm{N}$ retention of $40 \mathrm{mg} / \mathrm{kg}$ body-weight was found to be $326 \pm 46 \mathrm{~kJ} / \mathrm{kg}$ body-weight.

The influence of energy intake on the efficiency of protein utilization is well documented (Allison, 1958). The results presented here provide further support to this. Net protein utilization (NPU) of dietary protein in these children was calculated from the $\mathrm{N}$ retained and the endogenous $\mathrm{N}$ loss, which was assumed to be $2 \mathrm{mg} \mathrm{N} / \mathrm{basal}$ energy. The NPU decreases from 0.60 at an energy intake of $418 \mathrm{~kJ} / \mathrm{kg}$ body-weight to 0.47 at an energy intake of $293 \mathrm{~kJ} / \mathrm{kg}$ body-weight. Thus, a decrease in energy intake of $30 \%$ i.e. from 418 to $293 \mathrm{~kJ} / \mathrm{kg}$ body-weight resulted in a similar extent of decrease in NPU.

The authors wish to thank the Director, National Institute of Nutrition, Hyderabad, for his keen interest during the conduct of the study. The authors also thank Dr P. Bhaskaram for her help and the subjects for their co-operation.

\section{REFERENCES}

Allison, J. B. (1958). Ann. N.Y. Acad. Sci. 69, 1009.

Calloway, H. D. \& Spector, H. (1954). Am. J. clin. Nutr. 2, 405.

Clark, L. C. \& Thompson, M. L. (1949). Analyt. Chem. 21, 1218.

Gopalan, C. \& Narasinga Rao, B. S. (1971). Ind. J. med. Res. 59, Suppl. 3.

Indian Council of Medical Research (1972). Tech. Rep. Ser. no. 18.

Inoue, G., Fujita, Y. \& Niiyama, Y. (1973). J. Nutr. 103, 1673.

Iyengar, A. K., Narasinga Rao, B. S. \& Reddy, V. (1979). Br. J. Nutr. 42, 417.

Jelliffe, D. B. (1966). Wld Hlth Org. Monogr. Ser. No. 53.

Joint FAO/WHO Expert Committee on Energy and Protein Requirements (1973). FAO. Nutr. Mtg Rep. Ser. no.

52 and Tech. Rep. Ser. Wld Hlth Org. no. 522.

Munro, H. N. (1951). Physiol. Rev. 31, 449.

Munro, H. N. \& Naismith, D. J. (1953). Biochem. J. 54, 191.

Nageswara Rao, C., Naidu, A. N. \& Narasinga Rao, B. S. (1975). Am. J. clin. Nutr. $28,1116$.

Narasinga Rao, B. S., Visweswara Rao, K. \& Naidu, A. N. (1969). Ind. J. Nutr. Diet. 6, 238.

Plough, I. .C., Iber, F. L., Shipman, M. E. \& Chalmers, T. C. (1956). Am. J. clin. Nutr. 4, 224. 